\title{
Phase Equilibria in the Metal-Sulfur-Oxygen System and Selective Reduction of Metal Oxides and Sulfides: Part I. The Carbothermic Reduction and Calcination of Complex Mineral Sulfides
}

\begin{abstract}
ANIMESH JHA, SANCHUAN TANG, and ANDREAS CHRYSANTHOU
The difference in the standard Gibbs free energy for the formation of any two oxides or sulfides is the chemical potential for selective reduction of metals from complex minerals. The magnitude of the Gibbs free energy difference is shown by plotting the univariant relationships for relevant sulfides and oxides. In this investigation, three examples of mineral sulfides are considered, and the experimental results are compared with the predicted thermodynamic calculations. These examples include the reduction conditions for nickel and iron sulfides and pentlandite $(\mathrm{Fe}, \mathrm{Ni})_{9} \mathrm{~S}_{8}$ and chalcopyrite $\left(\mathrm{CuFeS}_{2}\right)$ minerals. The reduction behavior of mineral sulfides, such as those of nickel, cobalt, iron, and copper, is illustrated by referring to both the sulfide and alloy phase equilibria. In particular, the solution thermodynamic properties of the metallic phase equilibria are featured for determining the physical chemistry of preferential or selective reduction of the metal oxides and sulfides. The mechanism for the reduction of the aforementioned sulfide minerals is explained with the aid of the governing phase equilibria for the calcination process. The results from the carbothermic reduction of sulfide minerals are also compared. The important roles of lime and calcium sulfate in controlling the emission of sulfurous gases during the reduction reaction are explained. A qualitative analysis of reduction reactions of nickel and iron sulfides is reviewed to provide a comparison of the mechanism for complex nickel-bearing minerals. The importance of these results in producing alloy and pure metallic phases is also examined.
\end{abstract}

\section{INTRODUCTION}

PYRITE-BASED minerals such as chalcopyrite $\left(\mathrm{CuFeS}_{2}\right)$ are one of the primary sources of copper, whereas nickel and cobalt occur both as oxides and sulfides. In general, copper is a more abundant metal than either nickel or cobalt. The association of various metallic species in minerals is determined by their chemical similarities. For example, the chemical dissemination of nickel and the less abundant cobalt in copper-iron-sulfide and arsenopyrite is likely due to the comparative ionic sizes of the base metals, leading to an easier substitution of the metallic ions in the mineral crystal lattice. In lateritic and limonitic mineral lattices, on the other hand, iron ions are partially replaced by nickel and cobalt ions; consequently, a complex multicomponent solid-solution mineral sulfide phase is formed. In nickeliferous silicates, notably in serpentine $\mathrm{Mg}_{6} \mathrm{Si}_{4} \mathrm{O}_{10}(\mathrm{OH})_{8}$, the magnesium ions are partially replaced by nickel, cobalt, and iron. This is because the ionic radius of $\mathrm{Mg}^{2+}(0.065$ $\mathrm{nm})$ is comparable with the ionic radii of bivalent transition metal ions, e.g., $\mathrm{Ni}^{2+}(0.072 \mathrm{~nm}), \mathrm{Fe}^{2+}(0.076 \mathrm{~nm})$, and $\mathrm{Co}^{2+}$ $(0.074 \mathrm{~nm})$. Laterites are also an important source for metals such as chromium, and hence their reduction behavior

ANIMESH JHA, Reader, formerly with the Department of Materials Technology, Brunel University, Uxbridge UB8 3PH, United Kingdom, is with the School of Materials, University of Leeds, Leeds LS2 9JT, United Kingdom. SANCHUAN TANG, Research Assistant, is with the Changsha Research Institute of Mining and Metallurgy, Changsha, People's Republic of China. ANDREAS CHRYSANTHOU, Lecturer, is with the Department of Materials, University of Surrey, Surrey GU2 5XH, United Kingdom.

Manuscript submitted February 7, 1995. makes an interesting investigation for alloy powder production via the reduction of laterites and limonites. The present investigation of the phase equilibria in the $M$ (metal)-S(sulfur)-O(oxygen) system is divided into two parts. Part I examines the carbothermic reduction of oxide and sulfide minerals in the presence of $\mathrm{CaSO}_{4}$ for achieving preferential separation of the constituent metallic species. The phase equilibria for a selective reduction of a complex sulfide matte in the presence of lime as a sulfur exchange medium are also discussed. In part II, the results obtained from the direct reduction of laterites and their major constituent transition-metal oxides are reported.

Nickel, chromium, and cobalt are metals of strategic importance. Their combined concentrations in any deposit rarely exceed a few percent. The total concentration of nickel and cobalt in the richest deposits can be as high as 5 to $6 \mathrm{wt}$ pct; while the leanest deposits may contain as low as $0.8 \mathrm{wt}$ pct. The presence of chromium often makes the metal extraction process economically more attractive when the deposits are particularly lean in cobalt. Chromium is not associated with the pentlandite mineral from Kalgoorlie, Western Australia, investigated in this article. It is often the case that the economic viability of the extraction process is determined by the relative concentrations of cobalt, nickel, and chromium in a given deposit, as well as the methods of extraction. ${ }^{[1]}$ Besides the value of the mineral deposit, the price of a metal in the world market very much depends upon the demand and the strictness of environmental legislation. For example, the fall in demand for copper coaxial cables for telecommunication networks in the 1970 s rendered mining and mineral beneficiation of 
lean copper sulfide deposits uneconomical. In the current climate of tighter environmental regulation compared to 2 to 3 decades ago, clean methods of production and recycling are becoming important factors in modern metal-making practice. Aspects of recycling and reclamation of nickel and cobalt from industrial waste, such as slags and speisses, have been extensively discussed by Boldt ${ }^{[2]}$ and in a monograph, ${ }^{\{3\}}$ respectively. We also briefly present schemes for $\mathrm{SO}_{2}$ emission control while producing nonferrous metals either from sulfide minerals or from mattes.

The principles of phase equilibria and solution thermodynamics are essential for the extraction and selective separation of metals from complex minerals. The liquid copper-iron matte is a good example of an ideal mixing of two constituent sulfides, whereas metallic iron and copper have an extensive tendency to demix, both in the solid and in the liquid states. ${ }^{[4]}$ Nickel and cobalt, on the other hand, dissolve extensively in copper and iron matrices. In the extraction of copper, traditionally, the immiscibility of iron and copper in the alloy and liquid phases has been overlooked for production of two relatively pure metals. Instead, the iron sulfide in the matte is oxidized for the generation of chemical heat to meet a part of the total energy requirement of the continuous copper-making process. Consequently, iron is permanently lost in the slag phase. The tonnage of iron lost can be appreciated from the following statistical data for the total production of metallic copper in Chile and Canada. In 1992, the total weight added up to 2.67 million metric tons of copper. ${ }^{[5]}$ Based on chalcopyrite mineral formulation, the equivalent weight of iron lost was 2.28 million tons, which is nearly one-third of the total annual production of steel (6.67 million tons) in Chile in the same year.

In this part of the present investigation, we have concentrated on three different aspects of the reduction of complex minerals. Section II of this article features theoretical aspects of metal oxide and sulfide reduction phase equilibria in the presence of calcium sulfate and lime for producing metallic species, either as an alloy or as individual metal from either a complex oxide or sulfide as starting material. Section III is devoted to the importance of the experimental results in relation to the calcination-roasting reaction and its potential for realizing a selective separation process. This article concludes with a discussion of the results of the carbothermic reduction of pentlandite mineral in the presence of lime for producing iron-nickel alloy powder. The influence of imposing an external chemical potential (e.g., by fixing $\mathrm{CO}$ or $\mathrm{SO}_{2}$ partial pressure) is also discussed with a view of achieving a selective reduction of the metallic species from complex mattes.

\section{REDUCTION-CALCINATION PHASE EQUILIBRIA FOR NICKEL-OXIDE-BEARING CONCENTRATES}

The direct reduction of lateritic ores, for example, in a shaft furnace in the presence of gypsum yields a nickel sulfide matte phase for which the governing equilibrium reactions are shown in Eq. [1]. During the descent of the nickeliferous burden mixed with gypsum and coke in the shaft furnace, nickel oxide transforms into a nickel-sulfide matte at elevated temperatures via reaction [1]. Nickel mon- osulfide (NiS) is less likely to be stable under these conditions because it has a natural tendency to transform into a lower sulfide $\mathrm{Ni}_{3} \mathrm{~S}_{2}$ above $1063 \mathrm{~K}$.

$$
\begin{aligned}
3<\mathrm{NiO}>+2<\mathrm{CaSO}_{4}>+9 & <\mathrm{C}> \\
& =<\mathrm{Ni}_{3} \mathrm{~S}_{2}>+2<\mathrm{CaO}>+9(\mathrm{CO})
\end{aligned}
$$

In the text, the solid, liquid, and gaseous phases are designated by $<>,\{\}$, and ( ) brackets, respectively. The value of the standard Gibbs free energy change $\left(\Delta G^{\circ}\right)$ for each mole of nickel sulfide produced in reaction [1] is $992,701-1488 T \mathrm{~J}$. The values of $\Delta G^{\circ}$ for deriving this equation and others in this text are taken from the compiled data in Reference 6 . From the condition $\Delta G^{\circ}$ equals zero at equilibrium, the derived value of $T_{e q}$ is $667 \mathrm{~K}$, above which the forward reaction dominates.

In the shaft-furnace operation, the thermodynamic activity of lime is reduced by forming a calcium silicate slag. On the other hand, if lime at a higher activity and closer to unity than in silicate slag is considered, the metallization of nickel and associated metals can take place with carbon via one of the types of reduction reactions, as shown in Table I. The metal formation is also possible without the presence of carbon, as shown subsequently. The Gibbs free energy change for these reactions is plotted as a function of the temperature in Figure 1 for three commonly associated metallic species, namely iron, nickel, and cobalt, with nickeliferous laterite, limonite, and pentlandite minerals. Relevant free energy data are shown in Tables I and IVb. From this figure, it is apparent that a significant difference in the redox chemical potential between two metals exists for all three types of reactions, described in Tables I and IVb. For example, the standard Gibbs free energy changes for the carbothermic reduction of pyrrhotite

$$
\begin{aligned}
<\mathrm{FeS}_{x}>+x<\mathrm{CaO} & >+x<\mathrm{C}> \\
= & <\mathrm{Fe}>+x<\mathrm{CaS}>+x(\mathrm{CO})
\end{aligned}
$$

and nickel sulfide

$$
\begin{aligned}
<\mathrm{Ni}_{3} \mathrm{~S}_{2}>+2<\mathrm{CaO} & >+2<\mathrm{C}> \\
= & 3<\mathrm{Ni}>+2<\mathrm{CaS}>+2(\mathrm{CO})
\end{aligned}
$$

are $133,090-148 T \mathrm{~J}$ and $143,975-172.8 T \mathrm{~J}$ per mole of $\mathrm{CO}$ gas formed, respectively. At a given temperature, e.g., $1273 \mathrm{~K}$, the difference in the standard Gibbs free energy relative to $\mathrm{Ni}_{3} \mathrm{~S}_{2}$ is $-21 \mathrm{~kJ}$, which yields the value 7.3 for the equilibrium partial pressure ratio $\left(P_{\mathrm{CO}}\right)^{\mathrm{Ni} /}\left(P_{\mathrm{CO}}\right)^{\mathrm{Fe}}$ at that temperature. In the preceding computation of the equilibrium partial pressure of $\mathrm{CO}$, it was assumed that the thermodynamic activities of metallic iron and nickel refer to their pure states, i.e., $a_{\mathrm{Ni}}$ and $a_{\mathrm{Fe}}$ are unit activity. However, this computed value will change if an alloy phase forms. Here, the superscripts designate the corresponding metallic phase in equilibrium with the $\mathrm{CO}$ gas. The value of this ratio, a measure of chemical potential difference between the stability of metallic nickel and iron at $1273 \mathrm{~K}$, shows that the metallization of nickel is possible at a higher pressure than that of iron. This chemical potential differential is sufficiently large to achieve a preferential separation of $\mathrm{Fe}$ from a matte mixture containing $\mathrm{FeS}$ and $\mathrm{Ni}_{3} \mathrm{~S}_{2}$. The preferential separation can be effected by imposing the partial pressure of $\mathrm{CO}$ in equilibrium with iron. This is depicted in Figure 2, which is redrawn ${ }^{[7]}$ by superimposing the Fe-C-O equilibria designated by curves $a b, b c$, and $b d$ 
Table I. Standard Gibbs Free Energy Change $\left(\Delta G^{\circ}\right)$ for the Matte and Metal Formation Reactions Relevant to Shaft Furnace Reduction of Lateritic Ores*

\begin{tabular}{|c|c|c|}
\hline & $\Delta G^{\circ}=\Delta H^{\circ}-T \cdot \Delta S^{\circ}, \mathrm{J}$ & $\log K_{127}$ \\
\hline 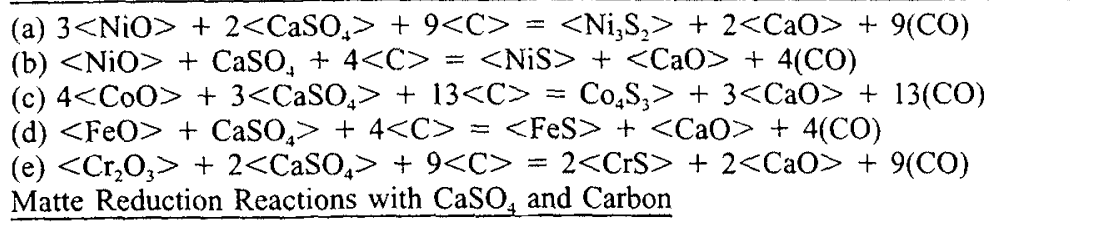 & $\begin{array}{r}992,701-1,488 T \\
455,157-667.6 T \\
1,577,201-2,215 T \\
474,675-661.1 T \\
1,322,521-1,528 T\end{array}$ & $\begin{array}{l}36.99 \\
16.19 \\
50.98 \\
15.05 \\
25.95\end{array}$ \\
\hline $\begin{array}{l}\text { (f) }<\mathrm{NiS}>+3<\mathrm{CaSO}_{4}>+<\mathrm{C}>=<\mathrm{Ni}>+3<\mathrm{CaO}>+4\left(\mathrm{SO}_{2}\right)+\mathrm{CO} \\
\text { (g) }<\mathrm{Ni}_{3} \mathrm{~S}_{2}>+6<\mathrm{CaSO}_{4}>+2<\mathrm{C}>=3<\mathrm{Ni}>+6<\mathrm{CaO}>+8\left(\mathrm{SO}_{2}\right)+2(\mathrm{CO}) \\
\text { (h) }<\mathrm{CO}_{4} \mathrm{~S}_{3}>+9<\mathrm{CaSO}_{4}>+3<\mathrm{C}>=4<\mathrm{Co}>+9<\mathrm{CaO}>+12\left(\mathrm{SO}_{2}\right)+3(\mathrm{CO}) \\
\text { (i) }<\mathrm{FeS}>+3<\mathrm{CaSO}_{4}>+<\mathrm{C}>=<\mathrm{Fe}>+3<\mathrm{CaO}>+4\left(\mathrm{SO}_{2}\right)+(\mathrm{CO}) \\
\text { (j) }<\mathrm{CrS}>+3<\mathrm{CaSO}_{4}>+<\mathrm{C}>=<\mathrm{Cr}>+3<\mathrm{CaO}>+4\left(\mathrm{SO}_{2}\right)+(\mathrm{CO}) \\
\text { Carbothermic Reduction of Matte in the Presence of Lime }\end{array}$ & $\begin{array}{r}1,055,665-798.3 T \\
2,151,700-1,617 T \\
779,103-581.3 T \\
1,064,242-783.2 T \\
1,112,611-783.1 T\end{array}$ & $\begin{array}{l}-1.62 \\
-3.83 \\
-1.60 \\
-2.76 \\
-4.75\end{array}$ \\
\hline $\begin{array}{l}\text { (k) }<\mathrm{Ni}_{3} \mathrm{~S}_{2}>+2<\mathrm{CaO}>+2<\mathrm{C}>=3<\mathrm{Ni}>+2<\mathrm{CaS}>+2(\mathrm{CO}) \\
\text { (l) }<\mathrm{Co}_{4} \mathrm{~S}_{3}>+3<\mathrm{CaO}>+3<\mathrm{C}>=4<\mathrm{Co}>+3<\mathrm{CaS}>+3(\mathrm{CO}) \\
\text { (m) }<\mathrm{FeS}>+<\mathrm{CaO}>+<\mathrm{C}>=<\mathrm{Fe}>+<\mathrm{CaS}>+(\mathrm{CO}) \\
\text { (n) }<\mathrm{CrS}>+<\mathrm{CaO}>+<\mathrm{C}>=<\mathrm{Cr}>+<\mathrm{CaS}>+(\mathrm{CO})\end{array}$ & $\begin{aligned} 287,952 & -345.5 T \\
80,364 & -104.2 T \\
133,090 & -148 T \\
180,852 & -147.2 T\end{aligned}$ & $\begin{array}{l}6.23 \\
2.14 \\
2.25 \\
0.27\end{array}$ \\
\hline
\end{tabular}

*Oxides and sulfides of coexisting metallic species cobalt, iron, and chromium with nickeliferous laterites are considered for the reduction in the shaft furnace.

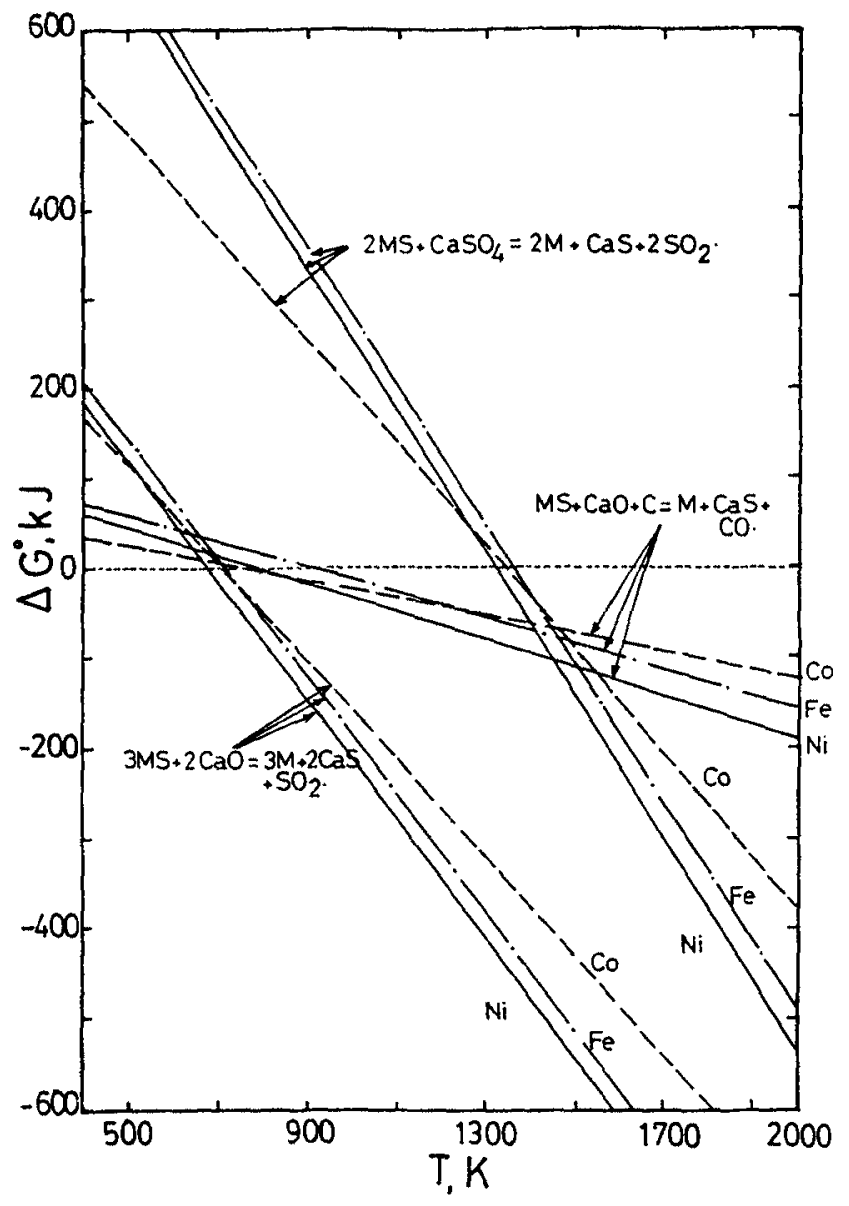

Fig. 1-Ellingham diagram for the reduction reaction indicating the Gibbs free energy differences between $\mathrm{Fe}, \mathrm{N} i$, and Co metals $(\mathrm{M})$ produced via calcination and reduction of the matte phase (MS).

for magnetite/iron, magnetite/wustite, and wustite/iron in equilibrium with $\mathrm{CO}$ and $\mathrm{CO}_{2}$ gas mixture, respectively. We find from this figure that the metallic iron and $\mathrm{CO}$ gas are in equilibrium with a unique iron-bearing crystalline

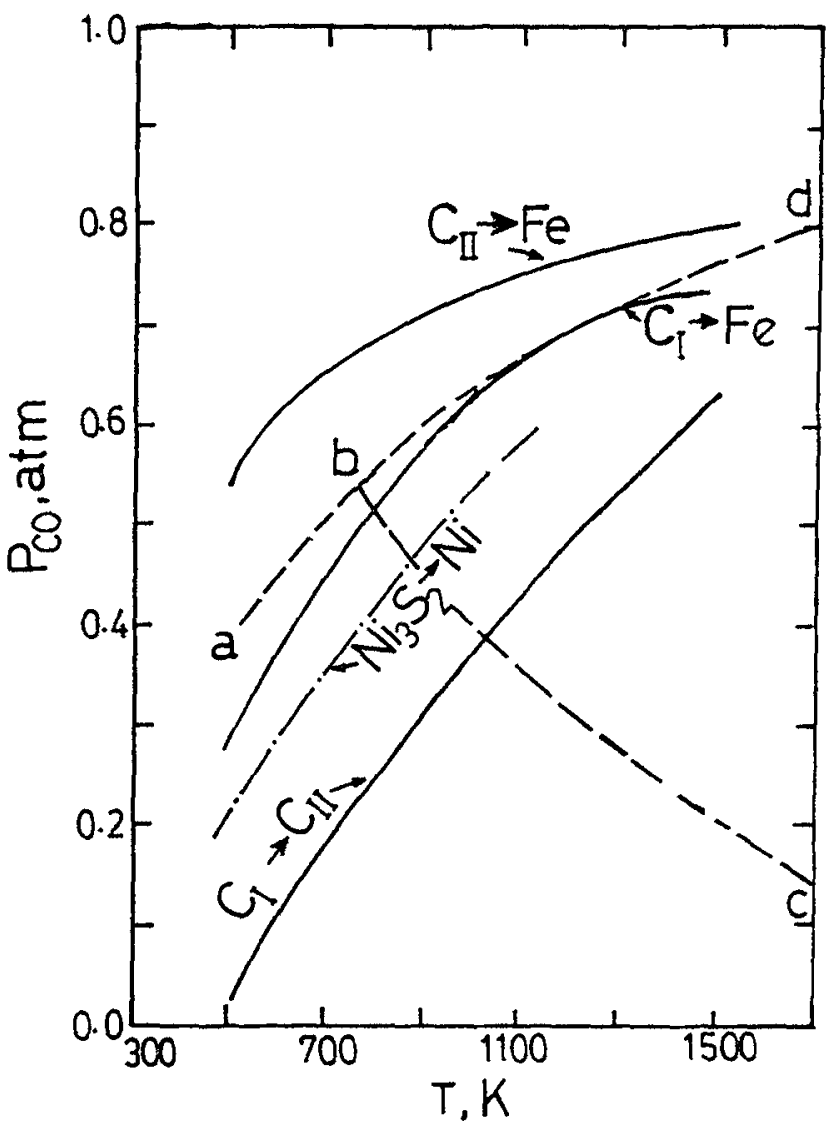

Fig. 2-The temperature dependence of the equilibrium partial pressures of $\mathrm{CO}$ gas in equilibrium with metallic iron and nickel. The solid ( $\longrightarrow$ ) and broken lines (....-) are for the $\mathrm{Fe}-\mathrm{Ca}-\mathrm{S}-\mathrm{O}$ and $\mathrm{Fe}-\mathrm{O}$ systems in equilibrium with $\mathrm{Fe}$ and $\mathrm{CO}$ and $\mathrm{CO}_{2}$ gas mixture, whereas the discontinuous curve $(\cdots \cdot \cdot)$ is for the $\mathrm{Ni}-\mathrm{Ca}-\mathrm{S}-\mathrm{O}$ system in equilibrium with $\mathrm{Ni}$ and $\mathrm{CO}$ and $\mathrm{CO}_{2}$ gas mixture.

phase $\left(\mathrm{C}_{1}: 4 \mathrm{FeO} .3 \mathrm{CaS}, \mathrm{C}_{\mathrm{II}}\right.$ : FeO.CaS, and $\mathrm{CaS}$ at $1273 \mathrm{~K}$, for example). In Figure 2, we have also compared the phase equilibrium line for the reduction of $\mathrm{Ni}_{3} \mathrm{~S}_{2}$. The formation 
Table IIa. Chemical Analysis of Kalgoorlie (Western Australia) Pentlandite Concentrate

\begin{tabular}{cccccccccccc}
\hline & $\mathrm{Ni}$ & $\mathrm{Cu}$ & $\mathrm{Co}$ & $\mathrm{Fe}$ & $\mathrm{S}$ & $\mathrm{Al}_{2} \mathrm{O}_{3}$ & $\mathrm{MgO}$ & $\mathrm{CaO}$ & $\mathrm{SiO}_{2}$ & Voluble $\mathrm{Matter}$ \\
\hline Wt pet & 9.9 & 0.8 & 0.2 & 34.6 & 31.9 & 1.2 & 4.9 & 1.7 & 9.8 & 5.0 \\
\hline
\end{tabular}

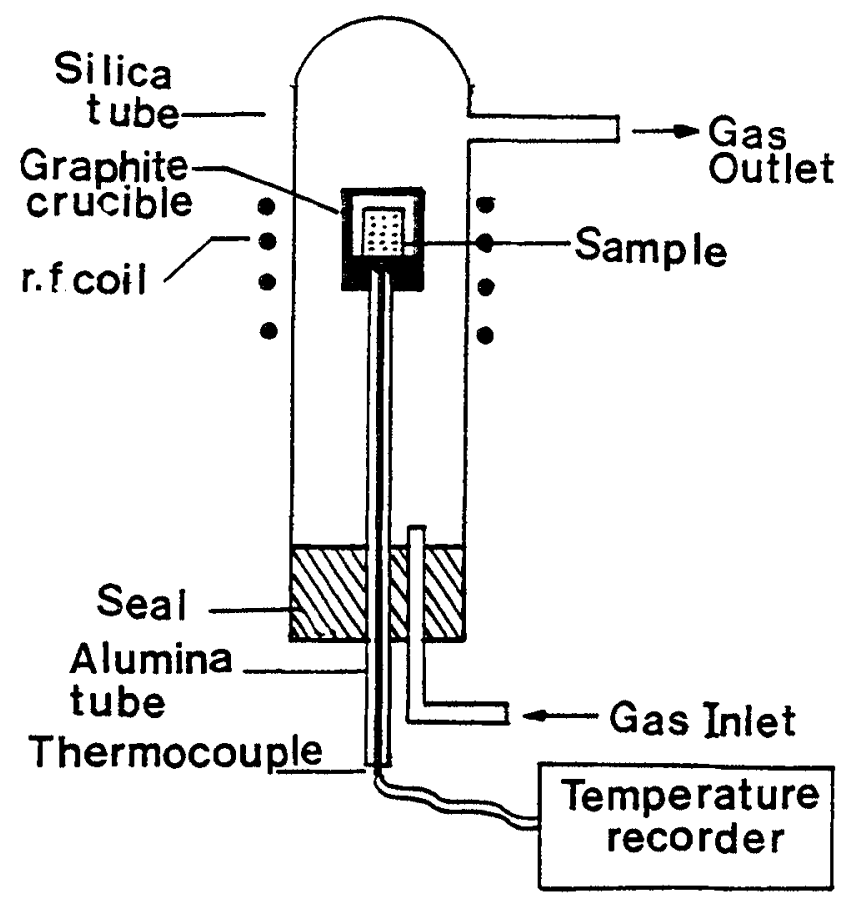

Fig. 3-Experimental setup showing the radio frequency heating coil for the reduction of pentlandite mineral with carbon and in the presence of lime.

of an alloy phase can be minimized during the course of the reduction reaction by maintaining a $\mathrm{CO}$ partial pressure either along or above the nickel sulfide line. This diagram can therefore be used in the same way for metal-making as the $\mathrm{Fe}-\mathrm{C}-\mathrm{O}$ diagram has traditionally been used for iron and steel making. Similar graphical illustrations, as shown in Figure 2, can be presented for the treatment of the complex mineral concentrate with gypsum.

By employing the aforementioned principles of phase equilibria, the lime which is generated as a result of the calcination-reduction reaction, can be separated either via magnetic or gravity separation technique from the metallic phase. The reclaimed lime can be used in the carbothermic reduction of sulfide matte. In this scheme of metal production, if nickel, iron, and cobalt oxides and sulfides are present in conjunction with copper sulfides, the partitioning of the metallic phase will become more effective, due to the stronger miscibility tendency of nickel and cobalt with copper than with iron. This behavior arises due to a large tendency to produce two virtually immiscible liquid and solid phases.

Thermodynamic calculations in Table I also indicate that chromium present in laterites can be sulfidized in the presence of gypsum at a much lower temperature than iron oxide. This result is important from the alloy-powder-manufacturing point of view, since chromium-and cobalt-rich nickeliferous laterites can then be directly reduced in a single-step process for producing metallic powder materials for high-temperature shape-forming processes.

\section{EXPERIMENTAI}

A. Experimental Procedure for Calcination Roasting and Reduction of Sulfide Minerals

Chalcopyrite $\left(\mathrm{CuFeS}_{2}\right)$ and related sulfide minerals were synthesized by using stoichiometric mixtures of constituent metallic materials with sulfur. Each mixture was sealed inside an evacuated silica ampoule. Details of the sulfide synthesis process have been discussed elsewhere ${ }^{[8]}$ together with the procedures adopted for the heat-treatment and reduction processes.

Pentlandite, a nickel sulfide concentrate mined at Kalgoorlie, was used for studying the calcination-roasting and carbothermic-reduction reactions. The chemical composition of Kalgoorlie pentlandite is shown in Table II, from which the composition of mineral sulfides present in pentlandite concentrate was derived. For the reduction of synthetic and naturally occurring sulfides to metal, the mineral sulfides were mixed with lime and carbon. The calcinationroasting reaction of mineral sulfides was studied by mixing dry lime with sulfide minerals in two different stoichiometric ratios, i.e., sulfide:lime $=1: 1$ and $1: 2$. These mixtures were pelletized by applying pressure of $20 \mathrm{MPa}$ using a steel die and a press.

\section{B. The Procedure for High-Temperature Reduction and Calcination of Mineral Sulfides and the Methods of Analysis}

All experiments, except those involving pentlandite mineral, were performed in a kanthal-wire resistance furnace equipped with a thermogravimetric balance, which allowed a continuous monitoring of the weight change during calcination and reduction reactions. The details of this experimental set-up are described in Reference 9. Pentlandite mineral mixed with dry lime was reduced in a graphite crucible which was heated by a radio-frequency induction coil. The experimental setup is shown in Figure 3. A silicaglass tube was used to isolate the reaction chamber from the outside air atmosphere. Experiments were conducted in a partially reducing and inert atmosphere by continuously purging the tube with an argon gas (99.99 pct purity) stream. The temperature of the pellet inside the coil was monitored by inserting a Pt-10 pct Rh-Pt alloy wire thermocouple inside the alumina support tube. Once the desired temperature inside the coil had been reached, each pellet was isothermally held for different lengths of time, varying between 30 and 120 minutes. In both types of heating experiments, the argon gas flow was maintained at a rate of $250 \mathrm{~mL} / \mathrm{min}$ for sweeping $\mathrm{SO}_{2}$ and $\mathrm{CO}$ gases out of the silica reaction chamber during the course of calcinationroasting and carbothermic-reduction reactions, respectively.

At the end of each reaction, the pellets were quenched from the isothermal reduction temperature to room temperature. This was achieved by withdrawing the silica reaction tube from the hot zone of the resistance-heated furnace into the room temperature zone. However, in the radio-fre- 
Table IIb. Chemical Formula of Mineral Sulfides Based on the Composition of Metallic Species (Excluding Oxide Constituents)

\begin{tabular}{|c|c|c|c|c|c|c|}
\hline & $(\mathrm{NiFe})_{4} \mathrm{~S}_{8}$ & $\mathrm{FeS}_{2}$ & $\mathrm{Cu}_{2} \mathrm{~S}$ & $\mathrm{CoS}$ & Oxides & Voluble matte \\
\hline Calculated wt pct & 45.4 & 30.7 & 1.0 & 0.3 & 17.6 & 5.0 \\
\hline
\end{tabular}

quency heating method, the power was switched off, thereby allowing the pellet and the crucible to cool down rapidly. The cooling time from the isothermal hold to room temperature in the resistance-heated furnace was slower than for the radio-frequency coil. This difference in the cooling rate arose due to the larger size of the thermal mass in the resistance furnace. The slower cooling rate, however, had only contributed marginally to the overall weight loss and had no effect on the phase constitution of the reaction product. After the reacted pellets cooled down to room temperature, they were analyzed for product phases by using $\mathrm{X}$-ray powder diffraction and microscopic techniques. A semiquantitative indication of the distribution of elements in the reacted pellets was obtained by analyzing the relevant areas using energy-dispersive X-ray spectroscopic techniques. The results of the mass balance and phase analyses were then correlated for the determination of the near-equilibrium phase relationships in the $\mathrm{M}-\mathrm{S}-\mathrm{Ca}-\mathrm{O}$ system and for establishing the mechanisms of calcination-roasting and reduction reactions. The experimental results were also compared with the predicted phase relationships from the thermodynamic calculations.

\section{RESULTS}

\section{A. Calcination Roasting of Simple and Complex Mineral} Sulfides with Lime in an Inert Atmosphere of Argon Gas

The results from the calcination-roasting heat treatment of nickel sulfide in the presence of lime at $1223 \mathrm{~K}$ are summarized in Table III together with the results of the phases identified in the reaction product. The calcination roasting of nickel sulfide in argon atmosphere yielded metallic nickel via a redox reaction between the constituent alkaline-earth oxide and metal sulfide. The redox reaction was accompanied with a large observed weight loss from each pellet, which indicated the evolution of a gaseous species. The observation of phases formed after reaction is consistent with the prediction of phases from the calculated thermodynamic phase equilibria for lime-assisted calcination-roasting reactions summarized in Table IV.

Copper sulfide was calcined under the same conditions at different isotherms. It was observed that above $1123 \mathrm{~K}$, metallic copper formed in coexistence with $\mathrm{CaSO}_{4}$ and $\mathrm{CuO}$ phases. No metallic copper was detected below this temperature in the reaction product by X-ray powder diffraction technique. The results of phase analysis also strongly indicated the evidence for the presence of a liquid phase associated with the $\mathrm{Cu}-\mathrm{Cu}_{2} \mathrm{~S}-\mathrm{CuO}$ ternary. The thermodynamic nature of this liquid is extensively discussed in Reference 9 . The roasting reaction also resulted in a reasonable loss of weight from the pellet. The calcination roasting of copper and nickel sulfides, ${ }^{[10]}$ however, contrasts with that of pyrrhotite. ${ }^{[8]}$ In the case of FeS, the weight loss sustained by the pellet was relatively insignificant between 1173 and $1273 \mathrm{~K}$, and the formation of metallic iron was not observed. These results together with the preliminary results of calcination of pentlandite and chalcopyrite are compared in Table III. The phase analysis demonstrated that the formation of intermediate oxysulfide complexes is quite common during calcination roasting of iron-bearing sulfides. These results support the predicted phase equilibrium relationships in Figure 2.

\section{B. Carbothermic Reduction Of Complex Sulfides}

In view of the earlier investigation $s^{[8-11]}$ on the reduction behavior of pure nickel sulfide, the carbothermic reduction of pentlandite was carried out in the presence of lime in a flowing argon atmosphere. Some experiments were carried out with samples held at a preselected isotherm inside the radio-frequency induction coil for a period of 60 minutes, while others were performed for longer periods of time. The observed weight loss for each experiment has been tabulated after subtracting the mass of voluble matter, which totaled $5 \mathrm{wt}$ pct. The remaining observed weight loss $(\Delta W)_{r}$ could therefore be attributed to the partial loss of sulfur from the constituent sulfides, water vapor associated with hydrated lime invariably picked up during handling of powder mixtures and pellet preparation, and $\mathrm{CO}$ gas, which is a gaseous by-product of the carbothermic reduction. The liberated vapor of sulfur, as a part of the total weight loss, $\Delta W_{T}$, was experimentally estimated to be as large as $3 \mathrm{wt}$ pct. Sulfur invariably distills off from the pressed pellets while being rapidly heated to the experimental isotherm. We can therefore define $\Delta W_{\text {obs }}$ as $\left[(\Delta W)_{T}-3\right]$ wt pct. From the values of $\Delta W_{\text {obs }}$, the values of percentage reduction (pct $R$ ) were determined from the stoichiometry of the following reactions:

$$
\begin{aligned}
(\mathrm{Ni}, \mathrm{Fe})_{1.125} \mathrm{~S}+\mathrm{CaO}+(1+x) \mathrm{C}=1.125(\mathrm{Ni}, \mathrm{Fe}) \\
+\mathrm{CaS}+\mathrm{CO}+x \mathrm{C} \\
\mathrm{FeS}_{2}+2 \mathrm{CaO}+2 \mathrm{C}=\mathrm{Fe}+2 \mathrm{CaS}+2 \mathrm{CO} \\
\mathrm{FeS}_{2}=\mathrm{FeS}+1 / 2\left(\mathrm{~S}_{2}\right)
\end{aligned}
$$

In Eq. [3a], the value of $x$ represents the amount of excess carbon used in each experiment. From Table II, we know that $(\mathrm{Ni}, \mathrm{Fe})_{1.125} \mathrm{~S}$ and $\mathrm{FeS}_{2}$ constitute 45.4 and 30.7 wt pct, respectively, in the mineral pentlandite; therefore, a corresponding multiplication factor related to the weight percentages of the constituent sulfides has been used for estimating the value of the theoretical weight percent lost:

$$
\begin{aligned}
\Delta W_{\mathrm{S}} \text { (stoichiometric) } & =0.454\left(\Delta W_{3 a}\right)^{\mathrm{CO}} \\
+ & 0.307\left(\Delta W_{3 b}\right)^{\mathrm{CO}}+0.307\left(\Delta W_{3 c}\right)^{\mathrm{s}}
\end{aligned}
$$

From the total stoichiometric weight percentage of $\mathrm{CO}$, the values of percentage reduction (pct $R$ ) were estimated

$$
\text { pct } R=\frac{\left(\Delta W_{\text {obs }}\right)^{\mathrm{CO}}}{\left(\Delta W_{\mathrm{s}}\right)^{\mathrm{CO}}} \times 100
$$

The numerator and the denominator in Eq. [5] are desig- 
Table III. Summary of Phases Identified after Calcination Roasting of Simple and Complex Mineral Sulfides*

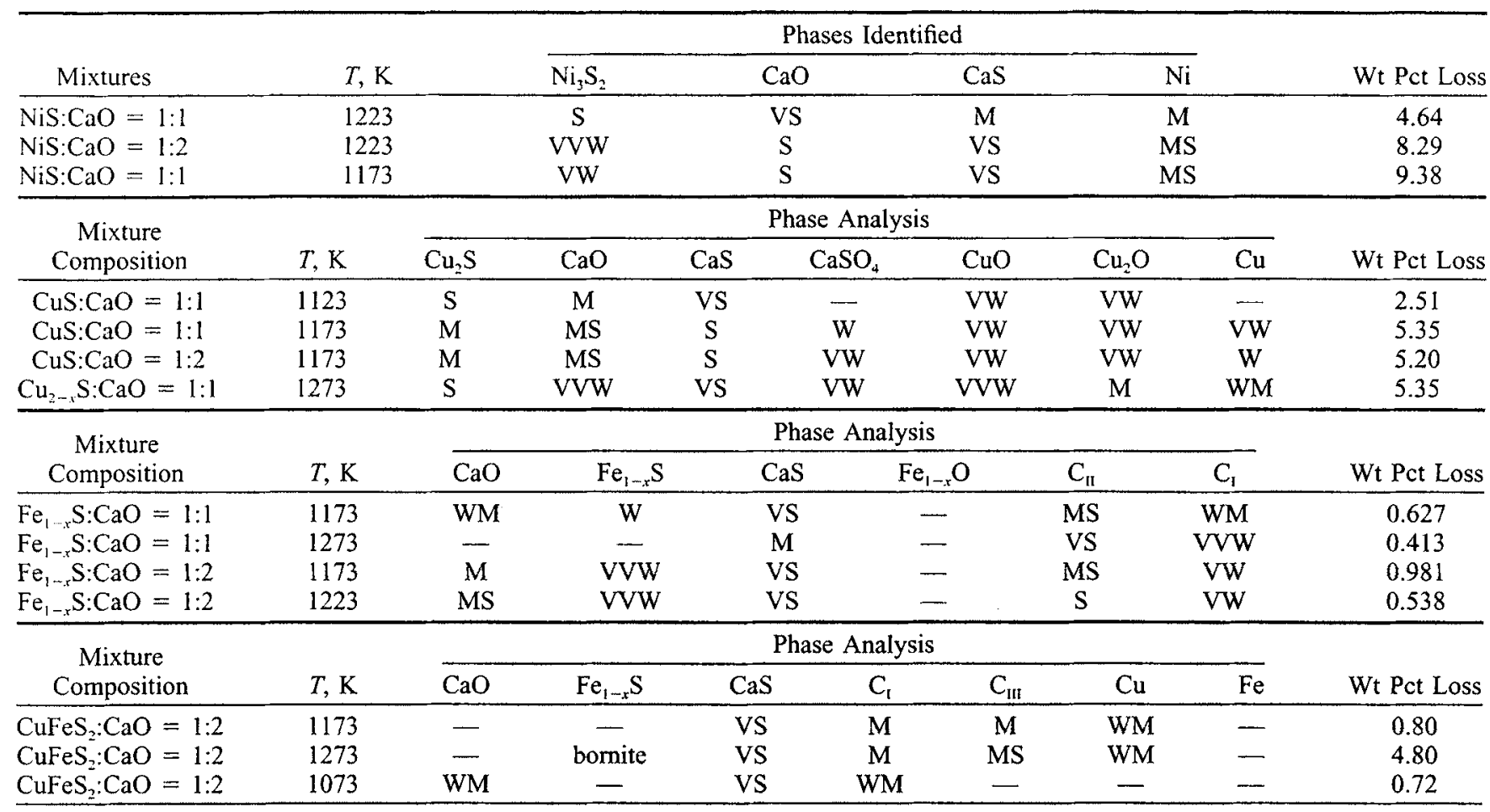

Bornite phase formed at $1273 \mathrm{~K}$. Neither FeS nor Fe phase was identified by powder diffraction. $\mathrm{C}_{\mathrm{n}}$ : absent.

\begin{tabular}{|c|c|c|c|c|c|c|c|c|c|}
\hline \multirow{2}{*}{$\begin{array}{c}\text { Mixture } \\
\text { Composition }\end{array}$} & \multirow[b]{2}{*}{$T, \mathrm{~K}$} & \multicolumn{7}{|c|}{ Phase Analysis } & \multirow[b]{2}{*}{ Wt Pct Loss } \\
\hline & & $\overline{\mathrm{CaS}}$ & $\mathrm{CaO}$ & $\overline{C_{I}}$ & $\mathrm{C}_{11}$ & $\mathrm{Fe}_{1-x} \mathrm{~S}$ & $(\mathrm{FeNi})_{9} \mathrm{~S}_{8}$ & $\mathrm{Fe}-\mathrm{Ni}$ & \\
\hline Pentlandite: $\mathrm{CaO}=1: 1$ & 1223 & VS & $\mathrm{VW} ?$ & WM & WM & W & VW & WM & 10.82 \\
\hline Pentlandite: $\mathrm{CaO}=1: 1$ & 1273 & VS & - & WM & WM & VW & - & WM & 14.76 \\
\hline
\end{tabular}

${ }^{*} K_{\alpha}$ radiation $=0.15418 \mathrm{~nm}$. Acronyms: $\mathrm{V}$-very, $\mathrm{S}$-strong, $\mathrm{W}$-weak, $\mathrm{M}$-medium; e.g., VS designates very strong relative intensity of a diffraction peak.

nated the total observed and the stoichiometric weight losses, respectively. The maximum value of the denominator in Eq. [5] is 20.5 wt pct. The new phases identified from X-ray diffraction analysis are summarized in Table $\mathrm{V}$. The estimated values of pct $R$ from Eqs. [4] and [5] are also included in this table. The lattice parameters of $\gamma$ phase (Fe-Ni alloy) derived from the calculated $d$-spacing data are summarized in Table VI. The X-ray results indicate that the cell dimension of the $\gamma$ phase is related to the dynamic equilibrium condition prevailing at the isothermal reduction condition.

From the measured $d$ spacings, the changes in the lattice parameters of solid-solution phases of $\mathrm{CaO}$ with $\mathrm{Ni}_{3} \mathrm{~S}_{2}, \mathrm{CaS}$ with $\mathrm{Ni}_{3} \mathrm{~S}_{2}$, and $\gamma$-iron with nickel are calculated, and these results are presented and compared with pure phases in Table VI. The symbol "?"' in this table indicates that the reported values are as large as the error in the determination of lattice parameters. These calculations show that the maximum reduction in the lattice parameters of $\mathrm{CaO}\left(a_{\mathrm{CaO}}=\right.$ $0.4812 \mathrm{~nm})$ and $\mathrm{CaS}\left(a_{\mathrm{CaS}}=0.56948 \mathrm{~nm}\right)$ as a result of $\mathrm{Ni}^{2+}$ ion substitution is 0.5 and $0.8 \mathrm{pct}$, respectively, at 1273 $\mathrm{K}$. The change in the lattice parameter of $\mathrm{CaS}-\mathrm{Ni}_{1.5} \mathrm{~S}$ solid solution with temperature is shown in Figure 4. This observed variation in the lattice parameter resembles a similar variation in the $\mathrm{CaO}-\mathrm{Ni}_{1.5} \mathrm{~S}^{[10]}$ and $\mathrm{CaO}-\mathrm{NiO}$ systems. The shape and the position of the solvus line for the $\mathrm{CaO}-\mathrm{Ni}_{1.5} \mathrm{~S}$ binary is somewhat different in the pentlandite reduction reaction when compared with the observed changes in the solvus line in the same binary during the carbothermic reduction of $\mathrm{Ni}_{1.5} \mathrm{~S}$. The estimated invariant temperature in both the $\mathrm{CaO}-\mathrm{Ni}_{1.5} \mathrm{~S}$ and $\mathrm{CaS}-\mathrm{Ni}_{1.5} \mathrm{~S}$ is around $1275 \mathrm{~K}$, which is higher than the $1123 \mathrm{~K}$ reported previously. ${ }^{[10]}$ The lattice parameter of the $\gamma$ phase, however, approaches the value of the cell dimension of $\gamma$ iron, and this trend appears to be consistent with the iron-rich side of the $\mathrm{Fe}-\mathrm{Ni}$ phase diagram. The maximum change in the lattice parameters of the $\gamma$ phase (Fe-Ni alloy) corresponds to a 2.2 pct reduction in the cell dimension with respect to pure (iron) austenite.

\section{DISCUSSION}

\section{A. Discussion of Cu-Fe-Ca-S-O System}

The results of the calcination of nickel sulfide summarized in Table III indicated that in the presence of lime and under inert atmosphere conditions, the formation of metallic nickel is encouraged. The sulfide-to-metal conversion process in the absence of carbon occurs as a result of the evolution of $\mathrm{SO}_{2}$ gas. From the values of $\Delta G^{\circ}$ in Table IV at different temperatures, the univariant line for each reaction was drawn by computing the value of $\log P_{\mathrm{SO} 2}$ at each temperature, obtained from the equilibrium constant relationship at the corresponding temperature. For example, for reaction $F^{\prime}$ in Table IV, the $\log K_{F^{\prime}}=\log P_{\mathrm{SO} 2}$ relationship 
Table IVa. The Expressions for Equilibrium Sulfur Dioxide Partial Pressure as a Function of Temperature Derived from the Standard Gibbs Free Energy Equation for Constructing Univariant Plots shown in Figures 4 and $5^{*}$

\begin{tabular}{|c|c|c|}
\hline \multirow[b]{2}{*}{ Reactions } & \multicolumn{2}{|c|}{$\log P_{502}=A / T+B, A t m$} \\
\hline & $A$ & $B$ \\
\hline \multicolumn{3}{|l|}{ Cu-Fe-Ca-S-O System } \\
\hline $\begin{array}{l}\left(\mathrm{A}^{\prime}\right)\left\{\mathrm{Cu}_{2} \mathrm{~S}\right\}+\left\{\mathrm{Cu}_{2} \mathrm{O}\right\}=6\{\mathrm{Cu}\}+\left(\mathrm{SO}_{2}\right) \\
\left(\mathrm{B}^{\prime}\right)\left\{\mathrm{Cu}_{2} \mathrm{~S}\right\}+2<\mathrm{CaSO}>=2\{\mathrm{Cu}\}+2<\mathrm{CaO}>+3\left(\mathrm{SO}_{2}\right) \\
\left(\mathrm{C}^{\prime}\right) 3\left\{\mathrm{Cu}_{2} \mathrm{~S}\right\}+2<\mathrm{CaO}>=6\{\mathrm{Cu}\}+2<\mathrm{CaS}>+\left(\mathrm{SO}_{2}\right) \\
\left(\mathrm{D}^{\prime}\right)<\mathrm{FeS}>+2<\mathrm{FeO}>=3<\mathrm{Fe}>+\left(\mathrm{SO}_{2}\right) \\
\left(\mathrm{E}^{\prime}\right) 3\{\mathrm{FeS}\}_{\text {mate }}+10<\mathrm{Cu} \mathrm{Cu}_{2}>=20\{\mathrm{Cu}\}+\mathrm{Fe}_{3} \mathrm{O}_{4}+3\left(\mathrm{SO}_{2}\right) \\
\left(\mathrm{F}^{\prime}\right) 3<\mathrm{FeS}>+2<\mathrm{CaO}>=3<\mathrm{Fe}>+2<\mathrm{CaS}>+\left(\mathrm{SO}_{2}\right) \\
\left(\mathrm{L}^{\prime}\right)<\mathrm{Cu}_{5} \mathrm{FeS}_{4}>+3<\mathrm{CaO}>=5<\mathrm{Cu}>+2<\mathrm{CaS}>+<\mathrm{C}_{11}>+\left(\mathrm{SO}_{2}\right) \\
\left(\mathrm{M}^{\prime}\right) 3<\mathrm{CuFeS}>+5<\mathrm{CaO}>=3<\mathrm{Cu}>+3<\mathrm{C}_{11}>+2<\mathrm{CaS}>+\left(\mathrm{SO}_{2}\right) \\
(\mathrm{Ni}, \mathrm{Co})-\mathrm{Fe}-\mathrm{Ca}-\mathrm{S}-\mathrm{O} \text { System }\end{array}$ & $\begin{array}{r}-3,280 \\
-12,381 \\
-14,064 \\
-16,757 \\
-13,470 \\
-15,005 \\
-14,476 \\
-5,948\end{array}$ & $\begin{array}{l}4.01 \\
7.77 \\
3.54 \\
5.90 \\
6.90 \\
5.61 \\
8.24 \\
4.68\end{array}$ \\
\hline $\begin{array}{l}\left(\mathrm{G}^{\prime}\right) 3\left\{\mathrm{Co}_{1.125} \mathrm{~S}\right\}+2<\mathrm{CaO}>=3.375\{\mathrm{Co}\}+2<\mathrm{CaS}>+\left(\mathrm{SO}_{2}\right) \\
\left(\mathrm{H}^{\prime}\right) 3<\mathrm{NiS}>+2<\mathrm{CaO}>=3<\mathrm{Ni}>+2<\mathrm{CaS}>+\mathrm{SO}_{2} \\
\left.\left(\mathrm{I}^{\prime}\right) 11 / 2\left\{\mathrm{Ni}_{3} \mathrm{~S}_{2}\right\}+2<\mathrm{CaO}>=41 / 2 \mathrm{Ni}\right\}+2<\mathrm{CaS}>+\left(\mathrm{SO}_{2}\right) \\
\left(\mathrm{J}^{\prime}\right)<\mathrm{NiO}>+2<\mathrm{FeS}>+<\mathrm{CaO}>=<\mathrm{Fe}_{0_{0.67}} \mathrm{Ni}_{0.33}>\text { alloy }+<\mathrm{CaS}>+\left(\mathrm{SO}_{2}\right) \\
\left(\mathrm{K}^{\prime}\right) 3<\mathrm{CrS}>+2<\mathrm{CaO}>=3<\mathrm{Cr}>+2<\mathrm{CaS}>+\left(\mathrm{SO}_{2}\right)\end{array}$ & $\begin{array}{l}-16,707 \\
-13,661 \\
-16,707 \\
-13,950 \\
-22,461\end{array}$ & $\begin{array}{l}9.75 \\
7.98 \\
9.50 \\
6.80 \\
5.48\end{array}$ \\
\hline
\end{tabular}

Table IVb. The Values of the Standard Gibbs Free Energy Change for Lime- and Anhydrous Gypsum-Assisted Calcination Roasting Reaction

\begin{tabular}{|c|c|}
\hline & $\Delta G^{\circ}=\Delta H^{\circ}-T \cdot \Delta S^{\circ}, \mathrm{J}$ \\
\hline \multicolumn{2}{|l|}{$\mathrm{CaSO}_{4}$-Assisted Calcination Roasting Reaction } \\
\hline $\begin{array}{l}\text { (A") }<\mathrm{Ni}_{3} \mathrm{~S}_{2}>+<\mathrm{CaSO}_{4}>=3<\mathrm{Ni}>+<\mathrm{CaS}>+2\left(\mathrm{SO}_{2}\right) \\
\left(\mathrm{B}^{\prime \prime}\right) 2 / 3<\mathrm{Co}_{4} \mathrm{~S}_{3}>+<\mathrm{CaSO}_{4}>=8 / 3<\mathrm{Co}>+<\mathrm{CaS}>+2\left(\mathrm{SO}_{2}\right) \\
\left(\mathrm{C}^{\prime \prime}\right) 2<\mathrm{FeS}>+<\mathrm{CaSO}_{4}>=2<\mathrm{Fe}>+<\mathrm{CaS}>+2\left(\mathrm{SO}_{2}\right) \\
\left(\mathrm{D}^{\prime \prime}\right) 2<\mathrm{CrS}>+<\mathrm{CaSO}_{4}>=2<\mathrm{Cr}>+<\mathrm{CaS}>+2\left(\mathrm{SO}_{2}\right) \\
\text { (E") } 2<\mathrm{Cu}_{2} \mathrm{~S}>+\mathrm{CaSO}_{4}=4<\mathrm{Cu}>+<\mathrm{CaS}>+2\left(\mathrm{SO}_{2}\right) \\
\text { CaO-Assisted Calcination Roasting Reaction }\end{array}$ & $\begin{array}{l}523.250-333.3 T \\
450,777-267.5 T \\
501.561-283.9 T \\
596,773-324.1 T \\
455,252-231.6 T\end{array}$ \\
\hline $\begin{array}{l}\text { (F") } 3<\mathrm{FeS}>+2<\mathrm{CaO}>=3<\mathrm{Fe}>+2<\mathrm{CaS}>+\left(\mathrm{SO}_{2}\right) \\
\left(\mathrm{G}^{\prime \prime}\right) 3<\mathrm{CrS}>+2<\mathrm{CaO}>=3<\mathrm{Cr}>+2<\mathrm{CaS}>+\left(\mathrm{SO}_{2}\right) \\
\left(\mathrm{H}^{\prime \prime}\right)<\mathrm{Co}_{4} \mathrm{~S}_{3}>+2<\mathrm{CaO}>=4<\mathrm{Co}>+2<\mathrm{CaS}>+\left(\mathrm{SO}_{2}\right) \\
\left(\mathrm{I}^{\prime \prime}\right) 3<\mathrm{Ni}_{3} \mathrm{~S}_{2}>+4<\mathrm{CaO}>=9<\mathrm{Ni}>+4<\mathrm{CaS}>+2\left(\mathrm{SO}_{2}\right) \\
\text { (J") } 3<\mathrm{Cu}_{2} \mathrm{~S}>+2<\mathrm{CaO}>=6<\mathrm{Cu}>+2<\mathrm{CaS}>+2\left(\mathrm{SO}_{2}\right)\end{array}$ & $\begin{array}{l}287.437-107.6 T \\
430.256-105.1 T \\
211.242-83.1 T \\
639,942-363.4 T \\
217.975-29.2 T \\
\end{array}$ \\
\hline
\end{tabular}

Table V. Summary of the Results of Mass Balance and Phase Analyses after Reduction of Pentlandite Minerals

\begin{tabular}{|c|c|c|c|c|c|c|c|c|c|}
\hline \multirow[b]{2}{*}{ Number } & \multirow[b]{2}{*}{$\mathrm{S}: \mathrm{CaO}: \mathrm{C}$} & \multirow[b]{2}{*}{$T, \mathrm{~K}$} & \multirow[b]{2}{*}{$t, \min$} & \multicolumn{2}{|c|}{ Mass Balance } & \multicolumn{4}{|c|}{ Phases Identified } \\
\hline & & & & $\Delta W_{\text {obs }}$ & Pct R & $\mathrm{CaS}$ & $\mathrm{CaO}$ & $\gamma$ & $\alpha$ \\
\hline NS3 & $1: 2: 1$ & 1273 & 60 & 18.8 & 91.7 & VS & $M$ & $M$ & W \\
\hline NS4 & $1: 1: 2$ & 1273 & 60 & 18.8 & 91.6 & VS & $\ldots$ & $\mathrm{M}$ & $\ldots$ FeS \\
\hline NS5 & $1: 2: 2$ & 1273 & 60 & 18.8 & 91.6 & VS & M & M & - \\
\hline NS6 & $1: 2: 3$ & 1273 & 60 & 17.3 & 84.4 & VS & $\mathrm{M}$ & M & W \\
\hline NS8 & $1: 2: 2$ & 1173 & 60 & 5.4 & 26.3 & VS & M & M & WM \\
\hline NS9 & $1: 2: 2$ & 1373 & 60 & 4.2 & 20.5 & VS & $M$ & M & - \\
\hline NS10 & $1: 2: 2$ & 1273 & 90 & 6.1 & 29.5 & \multicolumn{4}{|c|}{ data unavailable } \\
\hline $\mathrm{NS} 12$ & $1: 2: 2$ & 1623 & 30 & 19.3 & 94.2 & VS & $\mathrm{M}$ & $\mathrm{M}$ & VW \\
\hline
\end{tabular}

yields the value of the equilibrium partial pressure of $\mathrm{SO}_{2}$ gas at a given temperature $T$ for the calcination of FeS. The computed univariant lines for lime-assisted calcinationroasting reactions in the $\mathrm{Cu}-\mathrm{Fe}-\mathrm{Ca}-\mathrm{S}-\mathrm{O}$ systems are compared in Figure 5, from which it is apparent that the calcination roasting of $\mathrm{CrS}$ is thermodynamically the least favorable of the reactions considered. If, for example, the partial pressure of $\mathrm{SO}_{2}$ is maintained below $10^{-8}$ atm at $1273 \mathrm{~K}$ inside the roasting reaction chamber, all metal sulfides listed in Table IV, will be reduced to metal, except
$\mathrm{CrS}$. This is because for the reduction of $\mathrm{CrS}$ to metallic $\mathrm{Cr}$, the equilibrium partial pressure is $7 \times 10^{-13}$ atm at 1273 K. In Figure 5 , the univariant line $\left(E^{\prime}\right)$ for the matte/metallic $\mathrm{Cu} /$ magnetite equilibrium, obtained from the oxidation of $\mathrm{Cu}-\mathrm{Fe}-\mathrm{S}$ matte, has also been compared with other related metallization equilibria. The comparison of univariants for the reduction and oxidation processes reveals that the oxidative process yields iron silicate slag. At equilibrium. the activity of $\mathrm{FeS}$ can be expressed by using the following free energy equation derived from the FeS activity data in 
Table VI. Experimentally Determined Lattice Parameters of $\mathrm{CaS}, \mathrm{CaO}$ and $\boldsymbol{\gamma}$-phase after Reduction of Pentlandite Mineral at Different Temperatures*

\begin{tabular}{|c|c|c|c|c|c|c|c|}
\hline \multirow[b]{2}{*}{ Number } & \multirow{2}{*}{$\begin{array}{r}T, \mathrm{~K} \\
1273 \\
\end{array}$} & \multicolumn{3}{|c|}{ CaS Cell Dimension } & \multicolumn{3}{|c|}{ CaO Cell Dimension } \\
\hline & & $d_{222}, \mathrm{~nm}$ & $a, \mathrm{~nm}$ & $\Delta a, \mathrm{pct}$ & $d_{311}, \mathrm{~nm}$ & $a, \mathrm{~nm}$ & $\Delta a, \mathrm{pct}$ \\
\hline NSl & 1273 & 0.16370 & 0.5670 & -0.43 & - & $\ldots$ & - \\
\hline NS2 & 1273 & 0.16411 & 0.5685 & -0.17 & 0.14435 & 0.4787 & -0.50 \\
\hline NS3 & 1273 & 0.16446 & 0.5697 & -0.01 & 0.14485 & 0.4804 & -0.16 \\
\hline NS4 & 1273 & 0.16308 & 0.5649 & -0.80 & 0.14426 & 0.4780 & -0.50 \\
\hline NS5 & 1273 & 0.16435 & 0.5693 & -0.04 & 0.14474 & 0.4800 & -0.25 \\
\hline NS6 & 1273 & 0.16446 & 0.5697 & -0.04 & 0.14492 & 0.4806 & -0.12 \\
\hline NS8 & 1173 & 0.16428 & 0.5691 & -0.07 & 0.14460 & 0.4796 & -0.30 \\
\hline NS9 & 1373 & 0.16426 & 0.5690 & -0.08 & 0.14466 & 0.4798 & -0.30 \\
\hline \multirow[t]{2}{*}{ NS12 } & 1623 & 0.16423 & 0.5689 & -0.10 & 0.14464 & 0.4797 & -0.30 \\
\hline & $T, \mathrm{~K}$ & \multicolumn{3}{|c|}{$\gamma$-Phase Cell Dimension } & \multicolumn{3}{|c|}{$\alpha$-Fe Cell Dimension } \\
\hline Number & 1273 & $d_{111}, \mathrm{~nm}$ & $a, \mathrm{~nm}$ & $\Delta a, \mathrm{pct}$ & $d_{110}, \overline{\mathrm{nm}}$ & $a, \mathrm{~nm}$ & $\Delta a, \mathrm{pct}$ \\
\hline $\mathrm{NSl}$ & 1273 & 0.20602 & 0.3568 & -2.20 & - & - & - \\
\hline NS2 & 1273 & 0.20694 & 0.3584 & -1.72 & - & - & - \\
\hline NS3 & 1273 & 0.20769 & 0.3597 & -1.37 & 0.2030 & 0.2871 & $+0.16 ?$ \\
\hline NS4 & 1273 & 0.20675 & 0.3581 & -1.81 & - & - & - \\
\hline NS5 & 1273 & 0.20756 & 0.3595 & -1.42 & - & - & - \\
\hline NS6 & 1273 & 0.20739 & 0.3598 & -1.34 & 0.2030 & 0.2871 & +0.16 ? \\
\hline NS8 & 1173 & 0.20755 & 0.3595 & -1.42 & 0.2026 & 0.2865 & 0.0 \\
\hline NS9 & 1373 & 0.20725 & 0.3589 & -1.59 & - & - & - \\
\hline $\mathrm{NS} 12$ & 1623 & 0.20702 & 0.3587 & -1.64 & - & - & - \\
\hline
\end{tabular}

*All values are in nanometers $(\mathrm{nm})$. Error in the measured lattice parameters $= \pm 0.0003 \mathrm{~nm} . a_{\mathrm{Cas}}=0.56948 \mathrm{~nm} ; a_{\mathrm{CaO}}=0.4812 \mathrm{~nm} ; \gamma_{\mathrm{Fe}}=0.36469$ $\mathrm{nm} ; \gamma_{\mathrm{Ni}}=0.35239 \mathrm{~nm}$; and $\alpha_{\mathrm{fe}}=0.28665 \mathrm{~nm}$.

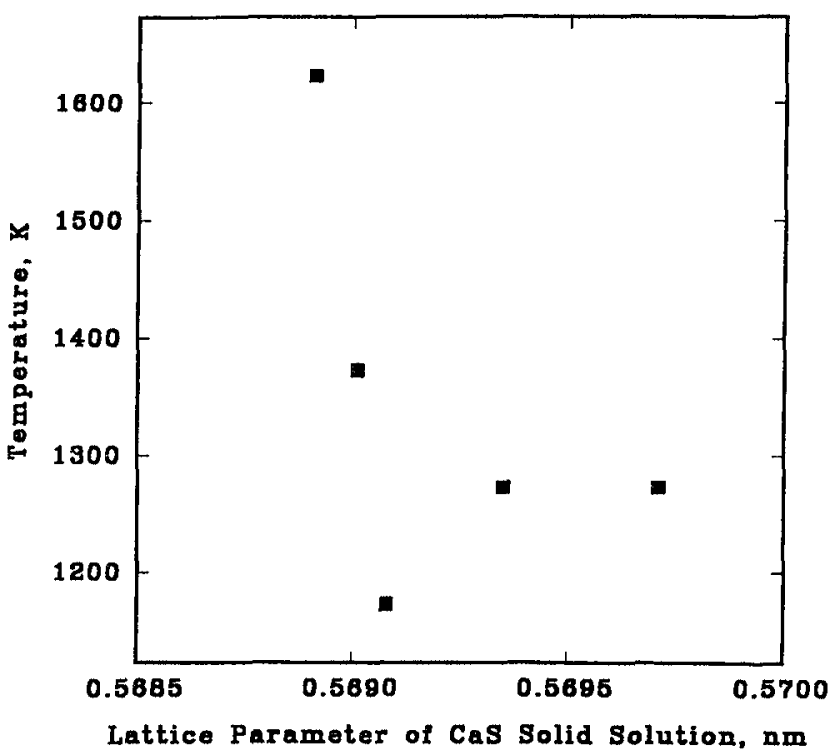

Fig. 4-The observed change in the lattice parameter of $\mathrm{CaS}-\mathrm{Ni}_{1.5} \mathrm{~S}$ solid solution phase as a function of the reduction temperature. The reduction of pentlandite minerals mixed with lime and carbon ( $\mathrm{S}: \mathrm{CaO}: \mathrm{C}=1: 2: 2)$ was carried out in the temperature range 1173 to $1623 \mathrm{~K}$.

Reference 12: $[\mathrm{FeS}]_{\mathrm{matte}}=\{\mathrm{Fe}\}+1 / 2\left(\mathrm{~S}_{2}\right)$ and $\Delta G^{\circ}=$ $591,377-175.4 T \mathrm{~J} \mathrm{~mol}^{-1} \mathrm{Fe}$. The activity of FeS in the $\mathrm{Cu}_{2}$ S-rich matte containing up to 1 wt pct oxygen drops from unity by 4 decades at $1500 \mathrm{~K}$. From Figure 5, we also find that the $\mathrm{Fe} / \mathrm{SO}_{2}\left(D^{\prime}\right)$ line intersects the $\mathrm{Cu} / \mathrm{CaS}\left(C^{\prime}\right)$ line at around $1123 \mathrm{~K}$. This point of intersection potentially suggests the existence of an invariant point and could be related with the observation of a liquid phase in the $\mathrm{Fe}-\mathrm{Ca}$ $\mathrm{S}-\mathrm{O}$ system reported by Koch and Trömel[13] and in our previous investigation. ${ }^{[8]}$ No metallic phase was observed

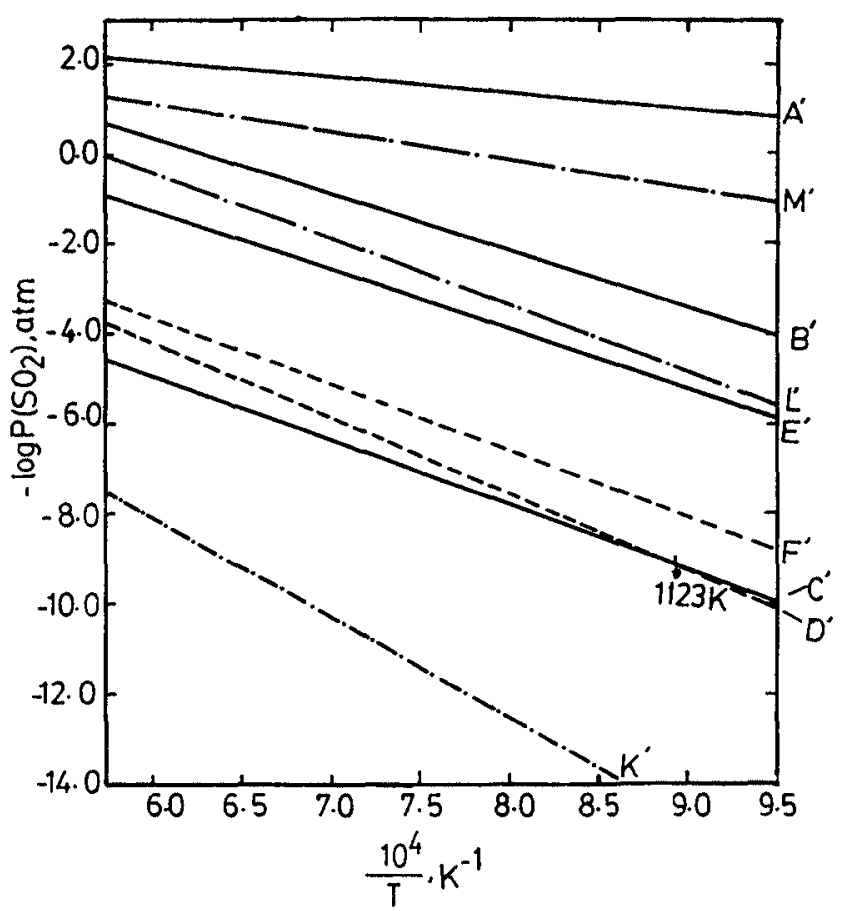

Fig. 5- $\log P_{\mathrm{SO} 2}$ vs $1 / T$ for Cu-Fe-Ca-S-O system indicating the stability regimes of the two metallic species, iron and copper, over a range of temperatures. The stability of metallic chromium is also compared. The lines for bornite and chalcopyrite minerals are also compared with pure sulfides (Table IV).

below $1123 \mathrm{~K}$ because both iron and copper form complex oxysulfide phases which only begin to separate preferentially above $1173 \mathrm{~K}$. Extensive separation of copper during calcination roasting of chalcopyrite and bornite, however, has been observed in one of our earlier investigations at 


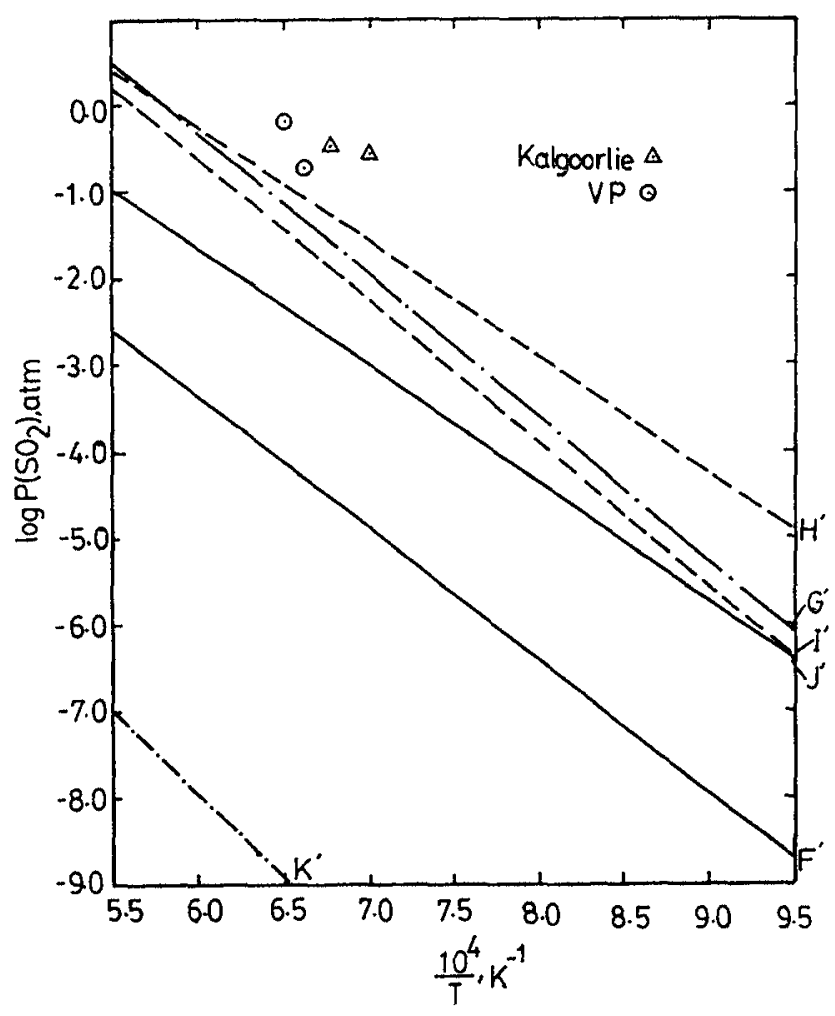

Fig. 6- $\mathrm{Log} P_{\mathrm{SO} 2}$ vs $1 / T$ for $(\mathrm{Ni}, \mathrm{Co})-\mathrm{Fe}-\mathrm{Ca}-\mathrm{S}-\mathrm{O}$ system indicating the stability regimes of the three metallic species, iron, nickel, and cobalt, over a range of temperatures. The stability of metallic chromium is also compared. The univariant line for the formation of the $\gamma$ phase $\left(\mathrm{Fe}_{0.67} \mathrm{Ni}_{0.33}\right)$ is also drawn for comparison.

and above $1173 \mathrm{~K}^{\left[{ }^{[1]}\right.}$ In Figure 5, the univariant lines $L^{\prime}$ and $M^{\prime}$ correspond to the calcination-roasting equilibrium for bornite and chalcopyrite, respectively. These two lines predict the equilibrium partial pressures of $\mathrm{SO}_{2}$ for the formation of metallic $\mathrm{Cu}$ and the iron-calcium oxysulfide phase $\left(\mathrm{C}_{11}\right)$ over a temperature range. The univariant lines $\left(C^{\prime}\right.$ and $\left.F^{\prime}\right)$ are also plotted for comparison of the differential in the chemical potential for metallic phase separation between iron and copper via the reduction of oxides with sulfides, e.g., lines $A^{\prime}$ and $E^{\prime}$, shown in Table IV. The current matte oxidation process adopted for copper-making indicates ( $c f . A^{\prime}$ and $\left.E^{\prime}\right)$ a difference in the chemical potential available for the separation of metallic copper from ironsilicate slags. Figure 5 shows that for achieving a selective separation of copper from iron during lime-fluxed calcination reaction, the magnitude of the $\mathrm{SO}_{2}$ chemical potential difference designated by the relative positions $F^{\prime}$ and $M$ univariants appears to be comparable with a similar difference in the chemical potential difference between lines $A^{\prime}$ and $E^{\prime}$.

\section{B. Discussion of $(\mathrm{Ni}, \mathrm{Co})-\mathrm{Fe}-\mathrm{Ca}-\mathrm{S}-\mathrm{O}$ System}

The graphical relationship, shown in Figure 5, can therefore be applied to carry out selective calcination for a range of metallic species. Nickel and cobalt can be separated from the mixture of sulfides at a relatively higher partial pressure of $\mathrm{SO}_{2}$ (e.g., $10^{-4}$ atm at $1273 \mathrm{~K}$ ) than either chromium or iron. Similarly, the univariant line for cobalt (in equilibrium with $\mathrm{Co}_{9} \mathrm{~S}_{8}$ ) is at a significantly lower $\mathrm{SO}_{2}$ potential than that for nickel (in equilibrium with NiS). In Figure 6, the line for the $\gamma$ phase (e.g., $\mathrm{Fe}_{0.67} \mathrm{Ni}_{0.33}$ alloy)/CaS $\left(J^{\prime}\right.$ line) is compared with those for $\mathrm{Ni} / \mathrm{CaS}(I)$ and $\mathrm{Co} / \mathrm{CaS}\left(G^{\prime}\right)$. The calcination-roasting experiments in this investigation yielded a nickel-rich $\gamma$ phase instead of achieving a complete physical separation of metallic species. The separation of $\mathrm{Fe}$ from $\mathrm{Ni}$, in practice, was not achieved due to the lack of a finer control of sulfur dioxide gas chemical potential, as suggested in Figure 6 . The outlined investigation has demonstrated theoretically and experimentally our predictions for the physical separation of iron from copper during calcination roasting. It also has experimentally verified the likelihood of ferrous alloy formation during the calcination roasting of complex minerals such as pentlandite. For this, the $\mathrm{SO}_{2}$ gas chemical potential differential could be used as a mechanism for either alloy formation or for metallic nickel separation from complex sulfide minerals by allowing iron $\left(\mathrm{Fe}^{2+}\right.$ ions) to be preferentially complexed with lime by forming a complex oxysulfide phase. The latter is practiced in conventional nickel production by forming an iron silicate slag in equilibrium with the $\mathrm{Fe}-\mathrm{Ni}$ sulfide matte phase.

\section{A General Discussion of Calcination Roasting}

As already mentioned, when chalcopyrite was calcined with lime (Table III), metallic copper formed together with complex oxysulfide phases. On this basis, the calcination roasting of pentlandite and chalcopyrite in the presence of lime have a major similarity. In the case of chalcopyrite, metallic copper forms because iron and copper have a very large positive deviation from ideal solution behavior in the temperature range $1000 \mathrm{~K}$ to $1400 \mathrm{~K}$. This behavior is consistent with the well-known problem of segregation of metallic copper at the grain boundary regions in steel containing small quantities of copper. The metallization reactions in both complex sulfides, however, proceed via the evolution of $\mathrm{SO}_{2}$ gas and indicate that the formation of the pure metal $(\mathrm{Cu})$ and the $\mathrm{Fe}-\mathrm{Ni}$ alloy phases ( $c f . \mathrm{Eq} .7$ and $\mathrm{A}^{\prime}$ in Table IV) are in equilibrium with $\mathrm{SO}_{2}$ gas. Therefore, it would be possible to define the sulfur dioxide partial pressure regimes for the separation of the metallic species by using the univariant relationships $\left(c f . \log P_{\mathrm{SO} 2}\right.$ vs the reciprocal of the absolute temperature, $T$ ), and these could be directly established from Figures 5 and 6 . A comparison between the reduction and oxidation of iron/nickel sulfide matte with the reactions which occur during copper-matte oxidation has been made. In this case, the data from the Kalgoorlie smelter and the VP smelting process ${ }^{[14,15]}$ have also been compared. Over a limited temperature and partial pressure range, the equilibrium between the nickel sulfide matte and iron-silicate slag appears to be consistent with the phase stability regime of calcium sulfate/Cu. This is not surprising because the equilibrium partial pressure of sulfur dioxide (matte/slag) is sufficiently large to form calcium sulfate. The behavior of this univariant would be expected to be similar to that of the matte/copper/magnetite equilibrium line. Unfortunately, the univariant could not be quantified because of the unavailability of the activity data for $\mathrm{Ni}_{3} \mathrm{~S}_{2}$ in the matte phase in equilibrium with iron silicate slag.

In practice, selective separation of metals from complex minerals can potentially be achieved in two ways: (a) in a differential temperature reactor having a constant $\mathrm{SO}_{2}$ partial pressure or (b) in a differential $\mathrm{SO}_{2}$ pressure reactor 
maintained at a constant isotherm. The principle of the separation of metallic species by the imposition of a chemical potential is not different from that of cobalt alloy phase separation during smelting of a complex oxide ore. The latter utilizes the difference in thermodynamic miscibility properties of metallic copper in cobalt, iron, and nickel. Consequently, a red alloy (copper-rich Co alloy) and a white alloy (Co-Ni-Fe) form.

In addition to the two different approaches developed for metallic species separation under Sections IV-A through C by thermally treating complex minerals, a third approach, described subsequently, considers the carbothermic reduction of sulfide minerals in the presence of lime as an anion exchange medium. This method could potentially be a better choice economically, since the thermodynamically predicted reduction temperatures required are considerably lower than for both shaft- and flash-smelting furnace operations. Additionally, the temperature differential for achieving the physical separation of metals from the reduction of complex minerals is also of a wider range compared to the calcination-roasting process in the presence of either lime or $\mathrm{CaSO}_{4}$.

\section{Reduction of Complex Sulfides in the Presence of Lime}

The carbothermic reduction of metal sulfides in the presence of lime is a two-stage process and has been verified earlier in our previous investigations. ${ }^{[8-11]}$ In this process, lime assumes the role of an anion exchange medium by which it converts into $\mathrm{CaS}$, and the metal sulfide concomitantly transforms into a metal oxide. In the ensuing step, carbon or $\mathrm{CO}$ reduces the metal oxide to the metal. The mechanism of nickel sulfide reduction is strongly dependent upon the $\mathrm{CaO}: \mathrm{C}$ ratio, the reactivity of carbon, and the reduction temperature. Their roles have been identified by Machingawuta and co-workers. ${ }^{[10]}$ These results were found to be consistent with other experimental results ${ }^{[16-20]}$ which predate the results in Reference 10 . The conclusions from our previous work on nickel and other sulfides differ radically. The main features in our conclusions are the role of the exchange reaction, hitherto unexplained by other works, ${ }^{[16-20]}$ and its effect on the carbothermic reduction reaction. In the absence of sufficient carbon, the exchange reaction $\mathrm{Ni}_{x} \mathrm{~S}_{y}+y \mathrm{CaO}=\mathrm{Ni}_{x} \mathrm{O}_{y}+y \mathrm{CaS}$ also contributes to the metallization reaction. The former step dominates the reaction by forming a metallic phase via reaction [6]:

$$
\begin{aligned}
&\left\{\mathrm{Ni}_{x} \mathrm{~S}_{y}\right\}_{\text {matte }}+2 y\{\mathrm{NiO}\}_{\text {matte }}= \\
&(x+2 y)<\mathrm{Ni}>+y\left(\mathrm{SO}_{2}\right)
\end{aligned}
$$

As a result, the $\mathrm{Ni}_{1.5} \mathrm{~S}$-rich matte phase remains in equilibrium with $\mathrm{CaS}-\mathrm{Ni}_{1.5} \mathrm{~S}$ and metallic nickel.

Based on the powder diffraction analysis of phases, the reduction behavior of pentlandite in the presence of lime and carbon bears a significant resemblance to the reduction behavior of pure nickel sulfide $\left(\mathrm{Ni}_{3} \mathrm{~S}_{2}\right)$ and pyrrhotite $\left(\mathrm{Fe}_{1-x} \mathrm{~S}_{x}\right)$. The similarity becomes more apparent when the results of the calcination roasting of constituent and complex sulfides are examined. Calcination roasting of pentlandite produces complex calcium oxysulfide phases, namely of the types $\mathrm{C}_{1}(4 \mathrm{FeO} .3 \mathrm{CaS})$ and $\mathrm{C}_{\mathrm{II}}$ (FeO.CaS) reported elsewhere, ${ }^{[8]}$ together with the $\mathrm{Fe}-\mathrm{Ni}$ alloy phase. However, the corresponding calcium-nickel oxysulfide crystalline phase does not exist. Instead, a solid solution of $\mathrm{Ni}_{1.5} \mathrm{~S}$ with $\mathrm{CaO}$ forms above $1123 \mathrm{~K}$ and is in equilibrium with metallic nickel. The formation of metallic nickel above $1123 \mathrm{~K}$ is always observed. This tendency for metallization after calcination roasting of pentlandite is a strong indicator of the enhanced thermodynamic activity of iron sulfide and nickel oxide, and this condition is essential for the alloy formation via a chemical reaction similar to Eq. [6], i.e.,

$$
\begin{aligned}
2 x\{\mathrm{NiO}\}_{\text {matre }}+ & \left\{\mathrm{Fe}_{1-x} \mathrm{~S}_{x}\right\}_{\text {mate }}= \\
& \{2 x \mathrm{Ni}+(1-x) \mathrm{Fe}\}_{\text {alioy }}+x\left(\mathrm{SO}_{2}\right)
\end{aligned}
$$

The complex oxysulfide phase found after partial reduction of pentlandite is therefore expected to have a significant solubility of nickel ions, since the size of $\mathrm{Ni}^{2+}(0.072 \mathrm{~nm})$ and that of $\mathrm{Fe}^{2+}$ ions $(0.076 \mathrm{~nm})$ are comparable, and the difference is only 5.5 pct. The phase analysis also indicates that the alloy phase is produced from the sequential reduction of the oxysulfide complex, i.e., $\mathrm{C}_{\mathrm{I}} \Rightarrow \mathrm{C}_{\mathrm{II}} \Rightarrow$ (alloy + $\mathrm{CaS})$. In this respect, the reduction sequence appears to be similar to that for pyrrhotite reduction. ${ }^{[21]}$

The pyrite phase decomposes to pyrrhotite, and its reduction to $\alpha$-Fe is well established elsewhere by one of the authors. ${ }^{[21]}$ The formation of $\alpha-\mathrm{Fe}$ is strongly dependent upon two factors: the ratio of lime to carbon in the pellet, and the temperature of the reduction reaction. During the reduction of pentlandite, as shown in Table $\mathrm{V}$, the formation of metallic iron $(\alpha-\mathrm{Fe})$ was only confirmed by X-ray powder diffraction technique in pellets NS3, NS6, and NS8. From the measured values of the $d$ spacings for the ironrich phase, it is evident that the $\alpha$ phase has a small solubility of nickel at $1273 \mathrm{~K}$. On the other hand, as shown in Table VI, metallic iron formed at $1173 \mathrm{~K}$ is almost pure. In these three experiments, we also found that the $\gamma$-phase lattice parameter assumes one of the largest values observed in our experiments.

The results of the calcination-roasting and reduction reactions unmistakably point out that the change in the chemical potential of metallic species present in the complex minerals can be affected by either changing the temperature or by adjusting the composition of the pellet, thereby affecting the concentration of the residual $\mathrm{SO}_{2}$. The third option may be the combination of both temperature and composition. The disproportionation of the metallic species into $\gamma$ and $\alpha$ phases, as shown in Table VI, supports the reduction and calcination-roasting related mechanisms of the metallic phase separation. The degree of phase separation is not extensive in the case of pentlandite and is somewhat obscured due to extensive alloy formation. This marginality of metallic phase separation between $\gamma$ and $\alpha$ phases, however, can be suppressed by manipulating the concentrations of $\mathrm{SO}_{2}$.

By comparison, the tendency to physically separate iron and copper during the carbothermic reduction of copperiron bearing mineral sulfides viz. chalcopyrite and bornite is more extensive due to the favorable condition of immiscibility between the metallic phases. ${ }^{[4]}$ In this case, the reduction behavior of $\mathrm{Cu}_{2} \mathrm{~S}$ in the $\mathrm{Cu}-\mathrm{Fe}-\mathrm{S}$ matte determines the onset of the reduction of pyrrhotite to iron. The latter does not commence until the oxygen potential drops to a critical value that will approximately correspond to a similar difference in the chemical potential, as shown in Figure 5 , between the univariants $M$ and $F^{\prime}$. 
If chromium sulfide is transferred in the matte phase as a result of the calcination reduction with anhydrous calcium sulfate in the presence of carbon, its simultaneous reduction with nickel and cobalt sulfide will favor a strong alloyforming tendency. In this case, the formation of chromium carbide will be suppressed due to the preference for the formation of a ternary $\mathrm{Ni}$-Cr-Co alloy phase during the carbothermic reduction of the mixture of $\mathrm{NiO}, \mathrm{Cr}_{2} \mathrm{O}$, and CoO. ${ }^{[22]}$ This behavior of chromium confirms that the Gibbs free energy of formation of chromium carbide is less negative than the free energy of mixing of chromium in the alloy phase.

\section{CONTROL OF $\mathrm{SO}_{2}$ EMISSION}

The proposed methods for preferential separation of metals either from complex sulfide minerals or from sulfide matte can potentially provide a clean route for base metal production. The concentration of $\mathrm{SO}_{2}$ is expected to be at least as rich as $20 \mathrm{vol}$ pct of the total gas evolved in order to facilitate an easier production of sulfuric acid. For example, if the metal extraction reaction, as defined by the equilibrium relationship $f$ in Table $\mathrm{I}$, is considered, the partial pressure of $\mathrm{SO}_{2}$ gas will rise, provided the partial pressure of $\mathrm{CO}$ in the reactor can be lowered together with the activity of $\mathrm{CaO}$ by forming a silicate slag phase. The mixture of $\mathrm{CO}$ and $\mathrm{SO}_{2}$ can also be utilized for enhancing the tendency for matte formation when using mixtures of sulfate and oxide concentrates. Alternatively, $\mathrm{SO}_{2}$ gas can be either scrubbed with lime inside the reactor or externally. The sulfated lime can then be used for metal production in a shaft furnace.

Similar possibilities for scrubbing of $\mathrm{SO}_{2}$ also exist during the carbothermic reduction reaction. In this case, calcium sulfide will form, which can then be either gravity separated or magnetically separated from the reaction product. Calcium sulfide is also an efficient self-desulfurizing agent. The desulfurization takes place when heated with calcium sulfate in an inert atmosphere: $3<\mathrm{CaSO}_{4}>+$ $<\mathrm{CaS}>=4>\mathrm{CaO}<+4\left(\mathrm{SO}_{2}\right)$. The calcination desulfurization is well documented $\mathrm{d}^{[23.24]}$ for producing lime and pure $\mathrm{SO}_{2}$. The $\mathrm{CO}$ gas is an important gaseous fuel by-product which can be used for meeting the energy requirement of any of the following steps of metal production: (a) charge preheating, (b) scrubbing tower preheating, (c) as reduction reactor fuel, and (d) metal carbonyl, $\mathrm{M}(\mathrm{CO})_{x}$, vapor formation for further purification. For this reason, it may be advantageous to produce more $\mathrm{CO}$ gas by allowing the carbothermic reaction to dominate the overall metal extraction process.

\section{CONCLUSIONS}

The phase equilibrium calculations indicate the possibility of the formation of not only a complex matte at a temperature below $1000 \mathrm{~K}$ during the carbothermic reduction of nickel-bearing oxide concentrates with $\mathrm{CaSO}_{4}$, but also an alloy phase above $1300 \mathrm{~K}$. The alloy phase can only form at a high thermodynamic activity of lime. From Figures 1 and 2 , it is also possible to achieve a preferential separation of the metallic species from complex mattes by imposing an external chemical potential.
The calcination of sulfides with lime also yields metallic and alloy phases. Experimental evidence confirms that the separation of the metallic species is more dominant in cases where the two metallic species (e.g., compounded iron and metallic copper) produced during calcination exhibit a tendency for demixing in the alloy phase. On the other hand, if the demixing tendency is reduced, the formation of an alloy phase, as found during calcination of pentlandite in an inert atmosphere, is observed. The inert atmosphere calcination of pentlandite also yields two solid-solution phases: $\mathrm{CaS}-\mathrm{Ni}_{1.5} \mathrm{~S}$ and $\mathrm{CaO}-\mathrm{Ni}_{1.5} \mathrm{~S}$. These two phases also exist during the carbothermic reduction of pentlandite. As a result of the reduction reaction, the $\gamma$-austenite phase forms.

The selective separation of nickel from iron during the calcination and reduction reactions is possible only under the influence of an imposed chemical potential, as applied in the conventional copper- and nickel-making process.

\section{ACKNOWLEDGMENTS}

We acknowledge the financial support from the government of the People's Republic of China. We also thank Professor V.N. Mishra, Kalgoorlie Metallurgical Laboratory, for providing the Kalgoorlie pentlandite mineral for this work. Further, we express our sincere thanks to Professor Colin Bodsworth for his valuable suggestions.

\section{REFERENCES}

1. C. Bodsworth: The Extraction and Refining of Metals, Ist ed., CRC Press Inc., Boca Raton, FL, 1994, pp. 44-46.

2. J.R. Boldt, Jr.: in The Winning of Nickel: Its Geology, Mining and Extractive Metallurgy, Ist ed., Paul Queneau, ed.. Methuen \& Co. Ltd., London, 1967, pp. 227-88.

3. Cobalt Monograph, prepared in collaboration with Battelle Memorial Institute, Colombus, $\mathrm{OH}$, Centre D'Information du Cobalt, Brussels, 1960, pp. 33-42.

4. O. Kubaschewski and C.B. Alcock: Metallurgical Thermochemistry, 5th ed., Pergammon Press, Oxford, United Kingdom, 1979, p. 400

5. 1994 Britannica Book of the Year, Encyclopedia Britannica Inc., Chicago, IL, 1994, pp. 578-579 and 583.

6. E.T. Turkdogan: Physical Chemistry of High Temperature Technology, 1st ed., Academic Press, New York, NY, 1980, pp. 524.

7. Animesh Jha, Brian S. Terry, and Paul Grieveson: Proc. Int. Conf. on Extractive Metallurgy of Gold and Base Metals, Kalgoorlie, Australia, 1992, V.N. Mishra, D. Halbe, and D.J. Spottiswood, eds., AusIMM, Parkville, Victoria, Australia, Oct. 1992, pp. 433-40.

8. A. Jha, U.O. Igiehon, and P. Grieveson: Scand J. Metall., 1991, vol 20, pp. 270-78.

9. A. Jha, P. Grieveson, and J.H.E. Jeffes: Scand J. Metall., 1989, vol. 18 , pp. $31-45$

10. N. Machingawuta, A. Jha, and P. Grieveson: Scand J. Metall, 1989, vol. 18 , pp. $81-88$.

11. A. Jha and P. Grieveson: Scand. J. Metall., 1992, vol. 21, pp. 12737.

12. T.B. Jorgensen, T. Rosenqvist, and T. Torgersen: J. Met., 1970, vol. 22, p. 39.

13. K. Koch and G. Trömel: Arch. Eisenhuttenwes., 1977, vol. 48, pp. 133-38.

14. A.G. Hunt, A.A. Kamkoy, and M.L. Sorokim: Proc. Int. Conf. on Extractive Metallurov of Gold and Base Metals, Kalgoorlie, Australia. 1992, V.N. Mishra, D. Halbe, and D.J. Spottiswood, eds., AuslMM, Parkville, Victoria, Australia, Oct. 1992, pp. 421-22.

15. V.P. Bystrov, A.N. Fyodorov, A.A. Komkov, and S.L. Sorokin: Proc. Int. Conf: on Extractive Metallurgy of Gold and Base Metals, Kalgoorlie, Australia, 1992, V.N. Mishra, D. Halbe, and D.J. 
Spottiswood, eds., AusIMM, Parkville, Victoria, Australia, Oct. 1992, p. 480 .

16. R.E. Cech and T.D. Tiemann: TMS-AIME, 1969, vol. 245, pp. $1727-$ 33.

17. J.D. Ford and M.A. Fahim: Metall. Trans. B, 1975, vol. 6B, pp. 46164.

18. M.C. Bronson and H.Y. Sohn: Metall. Trans., 1983, vol. 14B, pp $605-15$.

19. R.C. Kerby: Investigation Report No. IR 73-47, Mines Branch, Department of Energy, Mines and Resources, Ottawa, Canada, 1973.
20. P. Marier: Internal Report No. EMI 72-14, Mines Branch, Department of Energy, Mines and Resources, Ottawa, Canada, 1972.

21. A. Jha and P. Grieveson: Scand. J. Metall., 1992, vol. 21, pp. 50-62.

22. Animesh Jha and Eoghan T. Doyle: EPD Congr. TMS Meeting, San Diego, CA, 1992, J.P. Hager, ed., TMS, Warrendale, PA. 1992, pp 745-58.

23. E.T. Turkdogan: Physical Chemistry of High Temperature? Technology, Ist ed., Academic Press, New York, NY, 1980, pp. 296303.

24. A. Jha and P. Grieveson: Scand. J. Metall, 1990, vol. 19, pp. 39-48. 